\title{
Methodology for Teaching Students the Analysis of Turkish Fiction Texts
}

\author{
Asiya Rizvanovna Rakhimova ${ }^{1} \&$ Alsu Mansurovna Nigmatullina ${ }^{1}$ \\ ${ }^{1}$ Kazan Federal University \\ Correspondence: Asiya Rizvanovna Rakhimova, Kazan Federal University, Russia. E-mail: mega.sppa@mail.ru
}

Received: July 17, 2019

Accepted: September 12, 2019

Online Published: October 28, 2019

doi:10.5430/ijhe.v8n7p13

URL: https://doi.org/10.5430/ijhe.v8n7p13

\begin{abstract}
When preparing specialists of Oriental studies, reading fiction in the language being studied is very effective for mastering a foreign language. The fiction text reflects not only the richness of a language and style, but also features of the development of the standard language and changes in its lexical composition. It is also expedient not only to read the literature in the studied language, but also the ability to analyze a literary work in the language this work is written. For this purpose it is necessary to teach students to use literary terms and the style of scientific analysis. Such training facilitates students' understanding of literary works in the language they study, and they use those works when writing course and diploma research papers. This article examines the stages of forming students' ability to analyze a literary work in the studied language. The important stages are the following 1) mastering literary terms and expressions, 2) the use of scientific style in the oral or written analysis of a work. In addition, the teaching comparative-contrastive analysis of the works of Turkish and Russian authors is another significant aspect of the methodology for teaching students the analysis of literary works.
\end{abstract}

Keywords: Turkish literature, Turkish, terms of literary criticism, in the studied language, stages of teaching

\section{Introduction}

Linguistics and literary criticism are fundamentally different sciences, because they pursue the study of different problems. The object of linguistics is the study of human language, rather than literature. A literary study is supposed to study fiction, its patterns and peculiar features.

Despite different objectives, linguistics and literary criticism work closely together. Like many phenomena of literature, fiction is an important source for linguistic research, as by means of literature it is possible to trace the characteristics of changes in the languages of different peoples of the world. For Literary studies it is necessary to use linguistic studies to provide understanding the language of literature. Fiction text is one of the most optimal means of forming lexical skills, since exactly in a fiction text that we can find lexical units of different styles.

Students of Oriental studies are trained not only to retell, translate, use new vocabulary correctly, but also to understand the main idea, to see the features of author's particular writing, to put the work into certain cultural and literary context.

On senior courses the students have to work on their course research work on the 3rd course and graduate qualification work at the end of 4th course. The research work is to be written in the Russian language, however in the process of working on their paper the students are obliged to: 1) read works that are the sources of the study in Turkish (due to the requirements, students are offered topics that were not previously studied and works not translated into Russian, etc.); 2) to study the works of Turkish literary critics (these can be works both on general literary criticism and critical articles devoted to the work of individual writers and poets).

Due to such objectives, from the beginning of the third course (not later) the teachers of Turkish and the teachers of Turkish literature have to prepare students for research work, actively using the studied language in practice. In this article we try to analyze the process of teaching the students to study the works of literature in the Turkish language, to consider the stages of preparation and generalize our experience in this field.

Turkish literature of the 19th and especially the 20th century is very rich and complex, and it arouses great interest among other peoples. When preparing specialists in the Turkish language and literature, great attention should be given to studying literature, namely, to reflect the genre diversity (novels, stories, essays, plays, poems, etc.), literary schools and trends, artistic, compositional features of texts.

In this regard, literary works and biographies of writers, etc. should be studied not only in literature classes. At certain number of language classes (indicated in the curriculum under the name "Basic Oriental Language"), as well as part of 
the classes in other language disciplines ("Turkish Language Stylistics", "Turkish Language Composition", "Theory and Practice of Translation", etc.) it is necessary to study: 1) literary terms; 2) reading, translating and retelling of literary works; 3 ) oral and written analysis (in Turkish) of the works.

On the first stage of teaching students to use the Turkish literature, in our opinion, it is necessary to emphasize on mastering the vocabulary related to literary researches. Not only terms should be studied, but all words on this subject, because this work is conducted without detachment from the general process of teaching the language. For example, such words or expressions as hakikatları sergilemek - to show reality, abartmak - to exaggerate, algilamak - to study, aktarmak - to adapt (text), yorumlamak - to interpret, çağrışım is an association (ideas) and many which are characteristic of the language of literary researches.

At the first lesson, the teacher introduces students to the basic literary terms and their equivalents in Russian. The process of learning takes several stages: primary acquaintance, translation into Russian, recording under dictation. For example, edebi türler - literary genres, nazım - poetic work, nesir / düzyazı - prose, divan - collection of poems of any poet, gazel - small poetic form, contains 5-15 bates, tahallus - author's name indicated in the last beate, kaside is a large poetic form from 20-200 baits, aruz is a metric form, quantitative (i.e. quantitative) Arabic size, hikaye, öykü - story, ana fikir -, mizah - and many others. In bilingual dictionaries, as a rule, a small number of terms are included, and therefore a special dictionary of literary terms should be used (Edebiyat Terimleri Sözlügü̈).

Then, working on texts this primary list is filled up with new terms, words and there appears a small dictionary on literary criticism. Such educational dictionaries differ both from terminological dictionaries and ordinary lexical minimums, as they contain both terms and word-combinations, i.e. lexical complexes on the topic. For example, toplumcu gerçekçilik - socialistic realism, karakter yaratımı/ karakter yaratma - creation of character, yazarın yaratıcılığı - work of writer, romanın olay örgüsü - a plot of novel and many others.

As a result of this work students acquire confidence in understanding and in the use of vocabulary reading works on literary criticism or at the oral/writing analyses of works by Turkish authors. As texts for reading it is advised to use the articles from fundamental works of Turkish author Akhmed Kabakli (Kabaklı Ahmed, 1997). Some researches (for example, work of Z. Bakyrjyoglu, G. Aytach and others) can be a chrestomathy for classes (Bakırcioğlu N.Z., 1996; Bakhyt et al, 2018; Gürsel Aytaç, 1990; Hasibuan et al., 2019; Yazdekhasti, et al, 2015).

On the second stage, in preparation for reading, translating and retelling literary texts (fragments from works, short stories, poems etc.), effective there can be a parallel study of some topics at the language and literature classes. Reading the text and discussing complex linguistic phenomena and lexical units should be done in language lessons taught by a teacher of the Turkish language. The retelling of the same work and its analysis (the third stage) from the literary point of view should be conducted by the teacher of literature. At the same time, if the analysis of a work is done in writing, it can be considered a composition (turk. Kompozisyon), i.e. two marks are given - 1) for knowledge of Turkish and 2) for ability to analyze a literary work.

Another aspect of the methodology, discussed in this report, is the preparation of students for the contrastive-comparative analysis of the works of Turkish and Russian authors. Comprehension of the similar phenomena in Russian and Turkish literature leads to understanding of single literary process. Associate study of Russian and other literatures makes it possible to reveal both national and original content as well as universal content, to realize the unity of the spiritual, moral, humanistic criteria of the world literary process (Raspopova, 1998; Alwahdani, 2019).

Preparation of students for the contrastive-comparative analysis can be successful using the works of masters of short stories, novelists Omer Seyfetdin and Mikhail Zoshenko. Their literary activity fell out on first quarter of the twentieth century. The genre of social short story and satiric story occupies the central place in the works of these writers. The writers' appeal to the social theme determined their artistic vision, critical attitude toward surrounding. It is also noted, that it is characteristic for every writer to have a skeptical look to reality. Behind the merry laughter of O. Seyfetdin and M. Zoshenko bitter and deep pessimism are hidden. M. Zoshenko, being the successor to traditions of Gogol, early Chekhov, Leskov, came forward to be the founder of original comic short story (Chudakova, 1979). O. Seyfetdin in his turn introduces the new, and aims to create the really Turkish original short story (Eisenstein, 1968).

Thus, mastering the best standards of world literature and ability to analyze and to compare contributes to forming of ideas about content and originality of literary text, develops sense of language and style for them. 


\section{Materials and Methods}

We examined teaching students to analyze literary works which consists of some stages as a single process due to this consistent approach was used in the research. Besides it is considered to be reasonable to use a descriptive method to study the stages of teaching.

\section{Results}

The questions discussed in this research are to draw more attention to the text as phenomenon of literary culture, to unite linguistic and literary aspects of its study, to deepen an idea about text as a complex multidimensional phenomenon. The study of textual activity that is the basis of communication between people becomes a priority in the field of liberal arts and education on the whole.

A.A. Potebnya marked unbreakable bond of literary criticism and linguistics in Russian philology (Fesenko, 2004). In our case, a concept of Turkish literature includes the idea about a subject, aimed at improvement of the Turkish language in its literary form. The practice of teaching the course the Literature of Turkey to students-philologists supposes to consider the learning process in a broader, more complex approach, when the text is considered not only a source of new words and expressions, but also an esthetically completed literary unit.

Analyzing the text, students simultaneously learn to see the way it is organized and the way the form relates to the content. A wide historical and literary context, at classes, makes it possible to identify the common features of the era or a certain art movement presented in the text, to emphasize the characteristic features of the style for this particular author.

\section{Conclusion}

Summing up the results of this study, we believe that among the main tasks of students 'education is the active use of intersubject communications, which primarily involves students' interpreting skills in order to expand the complex context of this literary course. Thus from one side, Literature is understood as a material by means of which students master the world of foreign languages. On the other hand these educational disciplines change positions - foreign languages are used as means of getting information to form ideas about content and peculiarities of the process of development of modern foreign literature.

\section{Acknowledgments}

This work was funded by the subsidy allocated to Kazan Federal University for the state assignment in the sphere of scientific activities

\section{References}

Aytaç Gürsel. (1990). Çağdaş Türk Romanları Üzerine Incelemeler. Ankara: Gündoğan Ltd. Şti., - 504 s.

Alwahdani, A. (2019). The Impact of Trust and Reciprocity on Knowledge Exchange: A Case Study in IT Outsourcing, Journal of Information Systems Engineering \& Management, 4(1), em0084.

Bakhyt, S., Kalimbetov, B. \& Khabibullayev, Z. (2018). Possibilities of mathematical problems in logical thinking, Development of secondary education pupils. Opción, 34(85-2), 441-457.

Bakırcıŏlu, N. Ziya. (1996). Başlangıcından Günümüze Türk Romanı. 3. Baskı. İstanbul: Ötüken Neşriyat A.Ş., - 262 s.

Kabakl1, A. (1997). Türk Edebiyatı. V Cilt. İstanbul: TE Vakıf Yayınları, - 1024 s.

Fesenko, E.Ya. (2004). The theory of literature.

Chudakova, M.O. (1979). Poetics of Mikhail Zoshchenko. https://www.livelib.ru/book/1000324439-poetika-mihaila-zoschenko-m-o-chudakova

Hasibuan, A. M., Saragih, S. \& Amry, Z. (2019). Development of Learning Materials Based on Realistic Mathematics Education to Improve Problem Solving Ability and Student Learning Independence, International Electronic Journal of Mathematics Education, 14(1), 243-252. https://doi.org/10.29333/iejme/4000

Edebiyat Terimleri Sözlüğü. http://www.edebiyatbilgileri.com/10/edebiyat-terimleri-sozlugu

Pesotskaya, S.A. (2006). Informational and communicative approach to teaching in high school as a requirement of time (on the material of the course "Modern foreign literature") Izvestiya Tomsk Polytechnic University Edition № 
http://cyberleninka.ru/article/n/informatsionno-kommunikativnyy-podhod-k-prepodavaniyu-v-vuze-kak-trebova nie-vremeni-na-materiale-kursa-sovremennaya-zarubezhnaya\#ixzz4aot0HoxeThesis

Raspopova, S.S. (1998). The method of comparative analysis of Russian and foreign literatures in the course of 10 and 11 classes. http://www.dissercat.com/content/metodika-sopostavitelnogo-analiza-russkoi-i-zarubezhnoi-literatur-v-kurse-10 -i-11-klassov

Yazdekhasti, A., Erfan, N. \& Nazari, N. (2015). Investigating the Relationship between Spiritual Intelligence and Social Adaptation among Girl High School Students in Shahreza City, UCT Journal of Social Sciences and Humanities Research, 3(1), 20-23. 